\title{
Creeping Towards Multicultural Federalism in Contemporary Ethiopia: Assessing the Legal and Political Complicatedness
}

\author{
Solomon Emiru Gutema \\ Wollega University, School of Law
}

\begin{abstract}
From 1991 onwards federalism has been introduced as the best option of governance to ensure constitutionalism and democracy in Ethiopia in particular and in the Horn of Africa in general for the first time in history. Despite this fact, currently there are numerous political parties, Liberation Fronts, and governments, basing their political questions on quest for federation, unification, and secession (Independence) in Ethiopia. As a result of these divergent political questions; ethnic conflicts, inter-state and intra-state conflicts, rampant corruptions, and poverty are still remained as a brand of Ethiopia in particular and in the Horn of Africa in general. Consequently, the Horn of Africa, in which Ethiopia is considered as the center is globally known as a center of crisis. Accordingly, Ethiopia has been suffering from the prevailing contending political ideologies, legal, and practical problems; though she has been introducing and practicing multicultural federalism as her state structure since 1991. Hence, this research has the objective of analyzing the prevailing legal and political challenges against the present-day Ethiopian multicultural federalism. Consequently, as its research methodology; this research has employed: critical legal and political analyses, historical interpretations of multicultural federalism in Ethiopia and beyond, document analyses, observation and personal experiences of the researcher. Therefore, it has utilized a qualitative research method. Consequently, the findings of this research has pointed out that there is a legal, political, and practical problems in order to ensure genuine multicultural federalism in the present-day Ethiopia.
\end{abstract}

Keywords:Constitutionalism, Ethiopia, Federalism, Law, Politics

DOI: $10.7176 / \mathrm{JLPG} / 109-02$

Publication date:May $31^{\text {st }} 2021$

“Federalism is designed to prevent tyranny without preventing governance." Daniel Elazar, Exploring Federalism, 1987

\section{Introduction}

Ethiopia is one of the oldest countries in the world; though its formation and its borders haven been subjected to a contentious debate both internally and externally. Hence, the origin of Ethiopia as modern state in the perspectives of history, politics, and myth is very controversial. However, the modern Ethiopian Empire as a country was established by a king named as Minilik II in the late ninth centuries. Since, its establishment as a modern country; Ethiopia had ruled by absolute monarchies [1989-1974]. From 1974 up to 1991 Ethiopia had governed under Military Dictatorship. After the downfall of the Derg Regime (Military Rule) in 1991; federalism has introduced into Ethiopia and thereby a Federal and Democratic State Structure has established under the leadership of Ethiopian People's Revolutionary Front (EPRDF) (FDRE Constitution, Article 1). Nevertheless, the Federal and Democratic State Structure was recognized in 1991 onwards, after a disastrous civil war had been fought between various Ethnic Based Liberation Fronts and the then Central Government of Ethiopia. This Federal System, and the 1995 Federal Democratic Republic of Ethiopian Constitution (hereafter referred as 'FDRE Constitution' consists of golden principles which include: Supremacy of Constitution, Sovereignty of the people, Sanctity of Human Rights, Secularism, and Accountability and Transparency of the Government Officials at all levels (FDRE Constitution, Article 8-12).

Consequently, the concept of federalism and constitutionalism was therefore entered into Ethiopia in 1995 up on the Adoption of its first federal oriented constitution. Moreover, the Ethiopian brand of federalism has been disseminating to the neighboring states like the Republic of Somalia and Southern Sudan. Nevertheless, the fate of federalism as structure of state in Ethiopia in particular and in the Horn of Africa in general is not determined in this contemporary time. Since, the force of federation and disintegration are equally competing in the Horn States, including Ethiopia, Sudan, and Somalia at large presently.

Therefore, currently Ethiopia in particular and the Horn of Africa in general has branded with four competing political forces and agendas. Accordingly, this paper would like to present the four competing political interests in the following political matrix:

Firstly, there are political groups which strongly claim for federation [Hence they put federalism as the best option for state structure and government system in Ethiopia]. Secondly, there are unionist forces claiming to restore the old unitary state systems and thereby to ensure a nation state in Ethiopia. These groups condemn federalism; specifically multicultural federalism as a dangerous system which will result in disintegration and civil war at the end of the day. 
Thirdly, there are political groups which strongly claim for the right to self-determination up to secession. These groups comprise of Ethnic Based Political Parties; and therefore, they are struggling to make their ethnic group independent from domination or living in Ethiopia under the umbrella of multicultural federation. They claim that the present-day states of Ethiopia was created as a result of colonization, war and conquest [Imperial form of State], hence, it should be democratized or disintegrated. The fourth competing political force in Ethiopia is a fatal one; which is ideologically orchestrated by extremism or radicalism; hide and organized itself under both Christianity and Islamic religions. For instance, a political or religious ideology which consider Ethiopia as a holy land or a Christian state or country; a movement to establish an Islamic state in Ethiopia or in the Horn of Africa in general; the impacts of the Islamists 'Al-Shabaab' in Somalia can be categorized under this political matrix.

On the other hand, there are several legal challenges creeping towards multicultural federalism in Ethiopia. In general terms, lack of constitutionalism which includes but not limited to: lack of limited government, Prevalence of massive human rights violations; Lack of Free and Fair Election, lack of Accountability and Transparency of Government Officials, Lack of Rule of Law and the like are the main challenges to uphold the multicultural federalism in contemporary Ethiopia.

As a result of these prevailing dissenting political ideologies, and the legal challenges highlighted hereinabove, the Horn of Africa in which Ethiopia is a part is considered as a whole as the center of crisis in the eyes of global communities. Consequently, the Horn of Africa in general and Ethiopia as a country in particular have been suffering from continuous wars, conflicts, instabilities, disintegrations, rampant corruptions and poverty. From history and existing political practices; it seems that state building in the Horn of Africa including Ethiopia is neither completed nor successful till today. Hence, the problems of state building; and the quest for establishing and practicing constitutional, legitimate and democratic governance [constitutionalism] in the Horn of Africa including Ethiopia is never answered effectively until today; as we can witnessing from the prevailing political practices in this sub-continental region of Africa. Furthermore, the multicultural federalism which Ethiopia has adopted since 1991 as a system of government/state structure is phasing a serious challenges from the divergent political ideologies; and depleting at alarming rate as a result of lack of constitutionalism in contemporary Ethiopia.

Therefore, this paper has the objective of analyzing the prevailing challenges creeping towards multicultural federalism in contemporary Ethiopia in the perspectives of contending political ideologies, legal, historical, and practical problems.

\section{Objective of the Study}

The general objective of this research is to assess the legal and political complicatedness which are challenging the system of multicultural federalism in the present federalist Ethiopia. Specifically, this study has the objectives of assessing: the contending political ideologies; the legal challenges; like lack of constitutionalism, for instance; lack of limited government in practice; violations of massive human rights; non-prevalence of free and fair political elections, violations of the basic tenets of rule of law, historical, and practical as prevailing challenges to advance the ideology of multicultural federalism in the contemporary Ethiopia.

\section{Method of the Study}

This study has attempted to make an appropriate review of the existing literature on: the history of state building in Ethiopia and in the Horn of Africa at large; the concept of federalism and federation, the concept of constitutional or democratic governance [constitutionalism], as well as, the contending political ideologies and political parties moving within Ethiopia and the Horn of African states. It endeavors to assess the historical, legal and political challenges in forging viable states based on the ideology of multicultural federalism in Ethiopia.

Hence, to fulfill its objectives, this study has employed both 'black-letter methods' and 'law in context methods.' This 'Black-letter' method, focuses heavily, if not exclusively, upon the law itself; here, doctrinal legal research methods; which includes review of related literatures, legal and document analyses, comparing principles, case analysis, and theories have been utilized. On the other hand, this study has utilized 'Law in context method'; here, law itself becomes problem or a cause to the social problems; thus, this may be related to evaluating the non-law cases like politics, economy, social and others with law.

Specifically, this study has assessed critically the prevailing political and legal challenges to forge viable states in contemporary Ethiopia based on the system of multicultural federalism. Additionally, it has examined the factors which are challenging the system of multicultural federalism in Ethiopia in particular and in the Horn of Africa in general. Therefore, to achieve its objective, this study has employed a legal oriented methodology. Mainly critical legal and document analyzes, historical interpretations of the Ethiopian and the Horn politics, as well as, the practical observations in this region has utilized as a method of study. Thus, its research methodology is qualitative one. 


\section{Result and Discussion}

\subsection{The Concept of Federalism, Federation, and Multicultural Federalism}

The term 'federalism and federation' are used interchangeably in various literature frequently. Similarly, the earlier studies on federalism failed to make a distinction between 'federalism and federations' (William, 1964). However, there is a slight difference between these two terms. Accordingly, the term 'federalism' was deeply rooted in the Latin term "foedus" which refers to the "coming together of humans as equals to establish political bodies in such a way that all reaffirm their fundamental equality and retain their basic rights (Daniel, 1987). On the other hand, the term 'federations' refer to tangible institutional facts; they constitute the institutional and structural techniques for achieving one of the goals of federalism (Preston, 1982).

Thus, 'federalism' may be defined as 'a body of normative principles supporting the notion that a nation's sovereignty should be shared by a central entity and constituent units as a means of maintaining balance between the protection of minority groups (and their desire for self-government) and the need for the constituent units to act as one in the defense of their common interests' (Jean-Francois, 2011). 'The concept of 'federation', on the other hand, corresponds to political systems in which there are several orders of government whose institutional dimensions meet the normative principles of federalism' (Ibid). Shortly, federalism can be considered as an ideology while federation is concerned with political institutions matters (Michael, 1993).

Nevertheless, the concept of federalism as an ideology differs from time to time and from place to place as we can understand from history and the present practices. Consequently, the concept of federalism is the coming and joining together of some semi-autonomous states for some common goals in the context of older federation like USA. Hence, across Atlantic, federalism developed as a practical solution in response to a series of imperatives: 'first, as a means of uniting the Thirteen Colonies in their struggle to wrest independence from Great Britain, then to safeguard national cohesion after the failure of the Continental Congress, and finally, to maintain the integrity of the United States following the Civil War' (Jean-Francois, 2011).

On the other hand, within the context of the Europe [EU], it might refer to the coming together of the bulk of European states and the emergence of new institutions combining con-federal as well as federal features (John,1995). Within the context of former communist federations, federalism may mean the existence of some features associated with the division of powers in constitutional form rather than in operational reality (Ibid). In the African context, federalism is associated with the colonial experience of divide and rule (William, 1964). Therefore, federalism is different things for different people depending on history, culture, and political ideologies.

On the other hand, federalism may be either multinational federalism or Geographical federalism in its structure of organizing the sub-national governments/states/regions. The point is that in case of multicultural federations, the territories are designed on the basis of major diversities that define a certain society (K.C Wheare, 1963). Such federations presuppose the existence of a territorially grouped diversity (Graham Smith (1995). In the context of multicultural federations the main emphasis, among other things, is on federalism's ability to reconcile the forces of unity and diversity (K.C Wheare, 1963). Accordingly, multinational federalism, explores the possibilities for the democratic accommodation of national pluralism through federalism. Therefore, When there are different national groups living together within the same federation (or regional state), we call it a multicultural or a multinational federation (or a multinational regional state). For example federations like, Belgium, Canada, India, Spain, Swiss, and Ethiopia represents a multicultural/multinational federalism.

On the other hand, geographical or territorial based federalism is considered as the territorial approach (which is the conventional division of power into geographically defined constituent units rather than linguistic, cultural, ethnic or other bases of identity) (Thomas and Lidija 1996). These are considered as nation-federations aiming and working for national integration or assimilation. Unlike multicultural federation whose main concern is the accommodation of ethno-linguistic, religious and regional diversities; the uninational/geographical federation are working for strengthening a nation state; though they may sometimes give recognition for minorities, indigenous societies, and cultural groups in their respective countries (Ferran, 2005). Four instance, federations like Germany, Austria, and Australia are best examples of geographical federations.

Ethiopia has opted for federalism upon the verge of the down fall of the military dictator [the Derg Regime] or since 1991. Accordingly, she has introduced multicultural federalism as her state structure and governance system through adopting the 1995 FDRE Constitution in 1995. Hence, the 1995 FDRE Constitution has recognized the rights of self-rule/self-governance for the Ethiopian, Nations, Nationalities, and the People [FDRE Constitution, Preamble, Article 1, 8, 39, 46, 47, 48, 50, 51, and 52). Accordingly, several elements of multicultural federalism has recognized in the contents of the 1995 FDRE Constitution. For instance; this constitution gives recognitions to the Nations, Nationalities and Peoples; it guarantees the right to establish regional states based on ethno-linguistic lines; it imposes the duty on the government to respect the identity of Nations, Nationalities and Peoples; it recognizes the unconditional right to self-determination up to secession for the Ethiopian Nations, Nationalities and Peoples; it gives recognitions for all languages, ensure the right to freedom of religion, belief and opinion and others (FDRE Constitution, Article, 27, 39,47(2), 61, and 88). 
Nevertheless, the federal system in general and the multicultural federalism in particular has been phasing innumerable challenges in Ethiopia; since it was introduced in 1991. The main prevailing challenges to the system of multicultural federalism in Ethiopia includes but not limited to political, legal, and historical in its nature as assessed critically hereunder.

\subsection{The Challenges of Federalism and Multicultural Federalism in Ethiopia}

Federalism in its modern sense was introduced to Ethiopia up on the adoption of the 1995 Federal Democratic Republic of Ethiopian Constitution. Before 1991 Ethiopia had been ruled under various system of governance. For instance, traditional system of governance, monarchical and dictatorial government in her political history. Recently, the Ethiopian brand of multicultural federalism is on its way to disseminating to the neighboring countries like, the South Sudan and Somalia. However, the multicultural federalism as a system of state structure and governance in Ethiopia is phasing several prevailing challenges. Accordingly, the researcher would like to assess some of the major challenges hereunder; especially in the perspective of history, constitutionalism/legal challenges and dissenting political ideologies.

\subsubsection{Historical Challenges}

Historically African political scientists believed that federalism was imported to Africa as system of divide and rule. For instance, this assumption is serious in the perspectives of the Horn states. From the very beginning, the European colonial forces had divided African countries in various parts on the so called Berlin conferences of 1884-1885. They had introduced the system of divide and rules in their administration system during the colonial era; the best example is the Great Britain style. Hence, in Africa federalism is almost associated with the colonial forms of governance, as a result, only few countries have accepted federalism as their system of governance.

The same scenario is workable in the Ethiopian political history. Since, colonialism had left many political problems in the Horn of African in general and in the Ethiopian political history in particular. For instance, in the country of the Horn, the colonial powers had divided the countries of the Horn in various zones [states] as per their colonial interests not as per the interests of the indigenous people of Africa. The Italian colonialists had divided Ethiopia, into Eritrea and Ethiopia as Eritrea was controlled in 1890s. Somalia had divided among three colonial powers; namely Italy, Great Britain and France, Sudan was also slightly divided into North and South during the colonial era.

Accordingly, the colonial oriented division and separation of the countries have resulted in serious interstate and intra-state conflicts in the post-colonial period in Africa. For instance, the war of independence between Ethiopia and Eritrea [1962-1991(war of independence from Ethiopia), 1998-2000 (border conflict)], the chronic civil wars between the South Sudan and North Sudan (Central Government) [1983-2005] can be taken as a fruit of colonialism. Hence, historically federalism was assimilated with the system of governance employed by the colonialists; thus, many political scientists and political parties moving in Ethiopia relate the system of multicultural federalism with the system of divide and rule. Therefore, numerous political parties and politicians contest multicultural federalism as a fruit of colonialism in Ethiopia presently. Thus, they struggle to restore the former unitary state system to save Ethiopia from disintegration through dismissing the system of multicultural federalism in the Ethiopian politics.

\subsubsection{Lack of Constitutionalism /Legal Challenges to Multicultural Federalism}

In modern democratic governance system, the term constitution and constitutionalism are used inseparably. However, the two terms are quite different in political theory. Accordingly, 'Constitution' is both legal and political document which governs the legal, political and socio-economic aspects of certain nation. Constitution contains principles, objectives, values and guidelines on a very important national matters and interests like political, social and economic objectives. Moreover, it gives directions on country's foreign policy, election system, language policy, religion policy, matters of human and democratic rights, and system of governments, fiscal matters and others. Generally constitution serves as a framework for government organs, limits the power of governments, ensure rule of law and democracy, guarantee rights and freedoms for citizens, forging unity among diversities, develops human dignity and values which calls for sustainable development.

On the other hand 'Constitutionalism' deals with all about controlling, limiting and restraining the power of the state; hence, it is a legal limitation on government. 'Constitutionalism is the idea, often associated with the political theories of John Locke and the founders of the American republic, that government can and should be legally limited in its powers, and that its authority or legitimacy depends on its observing these limitations' (Stanford Encyclopedia of Philosophy, 2016). This means government must act as per the contents of the constitution which is already made. Hence, it is too difficult to list the elements of 'constitutionalism' exhaustively; nevertheless, one can understand the notion of constitutionalism by its elements as explained hereunder: Illustratively, the elements of constitutionalism includes but not limited to, 'Limited Government'; Respecting for Human and Democratic Rights; Sovereignty of the People; Free and Fair Election; Accountability and Transparency of Government Officials; Secularism; Supremacy of Constitution; Rule of Law and the like.

Moreover, constitutionalism enshrines respect for human worth and dignity as its central principle. To 
protect that value, citizens must have a right to political participation, and their government must be hedged in by substantive limits on what it can do, even when perfectly mirroring the popular will. As elaborated hereinabove, the concept of constitutionalism is too broad to define in single sentence. Nevertheless, it is possible to define 'constitutionalism' as the antithesis of arbitrary rule (Mohamed, 2013).Hence, in modern constitutional systems, the term constitutionalism has highly intermingled with the concept of limited and democratic government.

On the other hand, the mere fact of having a constitutional text doesn't witness the prevalence of constitutionalism in certain country. Since, constitutionalism is not the wording of the constitution; rather, it is all about implementing what has already promised in the constitutional texts in a day to day actions and inactions. Accordingly, ensuring constitutionalism is not simple like making, remaking or unmaking a certain constitution. Because, constitutionalism puts its emphasis on translating what is said or promised into action and reality. Subsequently in the political and legal life of nations, it is relatively easy to make a constitution; but it is more difficult to put it into practice, to implement it and be governed by it - which is what "constitutionalism" is all about.

Generally, the term constitutionalism can be revealed in three-faceted concepts; which includes, imposing limits on governmental powers, adherence to rule of law, and the protection of human rights (Kahn, 2003). Consequently, these three elements of constitutionalism have analyzed with respect to its impacts on the presentday Ethiopian multicultural federalism in the following manners:

\section{A) Lack of Limited Government as a Challenge to Multicultural Federalism in Ethiopia}

Practicing a genuine federalism in general and multicultural federalism in particular is unthinkable; unless, the principles of limited governments recognized in the text of the constitution are enforced and protected by a government of a certain federation. In simple talking, 'limited government' is a type of government in which its governmental power is limited by law/constitution. This means, the way in which certain government is established [come into power], the manner in which it is exercising its governmental power, and finally its duration in power is also limited by time. Therefore, if a government is a limited government, every aspect of such a government is already explained under the constitution. Accordingly, a limited government can attain the governmental power only and only by the will of its citizen, through a political process known as election. Hence, fair and free election is the most important element of limited government. Additionally, after elected and seized the political government certain government must be accountable and transparent in conducting its official duties. Furthermore, the office duration of certain government as an institution or as a leader must be restricted by specified time/years if it's a limited government. Consequently, this paper has assessed the extent to which these elements of limited government are enforced and protected in the present-day multicultural federalist Ethiopia in the following manner:

\section{i) Election Related Complicatedness in Ethiopia [Free and Fair Elections?]}

In broadly speaking, election is a decision-making process by which a certain population chooses an individual to hold formal office. Therefore, election is the act or process of choosing a person for political office, position or membership by voting. Accordingly, any political parties must come into power through election in modern democratic republic system of government. However, election must be fair, free, periodic, and by universal and equal suffrage, as well as, shall be held by secret ballot, guaranteeing the free expression of the will of the electors and thereby to confirm the existence of constitutionalism (The 1995 FDRE Constitution, Article 38). Thus, elections provide the mechanism through which people can exercise control over their government officials. They can either throw the rascals out if they do not like what is happening or they can reaffirm their support by re-electing officials they like. Nevertheless, the mere fact of conducting election periodically by certain country has never proved the existence of constitutionalism. Unless, the election is free, fair, periodic and by universal and equal suffrage in its nature, conducting election for name periodically is not a sign of constitutionalism. Consequently, genuine election is the symbol for the existence of genuine multicultural federalism. Accordingly the history of political election is not new in the history of Ethiopia. Hence, the evolution of election system in Ethiopia is assessed shortly from monarchical era to the present-day multicultural oriented federalist state.

Consequently, Ethiopia had governed by absolute monarchies [1889-1974]; Ethiopia was controlled by Italian colonialists, hence the monarchical system of governance was interrupted for five years [1935-1941], Ethiopia was also ruled by Military Dictatorship [1974-1991]. Consequently, during all these eras, the Ethiopian people had never known or seen the concept of free and fair election. During these periods the concept of election was rarely known among the Ethiopian people. Moreover, those elections conducted during the absolute monarchies and military dictatorship were discriminatory, unfair and not free elections.

However, following the paradigm shift from unitary to federal state structure since 1991, Ethiopia had conducted her first nationwide election in 1992. Since 1992 onwards, Ethiopia had been conducting periodic election per five years until 2015 [1992, 1995, 2000, 2005, 2010, and 2015]. Even the elections conducted in post 1991 [under the multicultural federalism] Ethiopia never knows the free and fair elections. For instance, in 
the 1992 election, the Oromo Liberation Front (the OLF) one of the principal actors during the Transitional Period had left the transitional process and expelled from the June 1992 election conducted in Ethiopia. Despite of the nominal coalition structure of the Ethiopian People's Revolutionary Front (the EPRDF), from the beginning, the Tigray People Liberation Front (TPLF) provided the leadership, ideological direction, for the majority of the fighters of the movement during the transitional government of Ethiopia or from 1991-1995 (John, 1998). Additionally, a Constituent Assembly formed after a separate election held on 5 June 1994 to complete and ratify a new constitution i.e. the 1995 FDRE Constitution is also taken place. Nevertheless, in both election (the 1992 regional elections and 1994) there was evidence of human rights violations in Ethiopia.

However, still even under the federal democratic republic governance system, Ethiopia has failed to conduct a free, fair and democratic election in the post 1995. Even in the worst scenario, gross human rights violation had taken place during these elections. Especially, the 2005 National Election of Ethiopia resulted in bloody crackdown between the civilian and government forces across the country. For instance, hundreds of peoples were massacred by the government security forces in Addis Ababa [the Capital City] in the post-election violent oriented demonstrations (The European Union Election Observation Mission Report, 2005). In the worst the Ethiopian government (Ruling Government- Ethiopian People's Democratic Front (EPRDF)) announced hundred percent victories in the election that was conducted in 2015.

Despite all these past worst connotations concerning National Election; it has hoped that if Ethiopia was preparing herself for conducting a genuine, acceptable, and democratic political election in 2020. Since the current ruling party [the Prosperity Party] was the result of a popular revolution that has come into power up-on the reforms that was taking place mainly during 2016- 2018 in Ethiopia. Nevertheless, the 'Prosperity Party 'or the present ruling party in Ethiopia came up with the agenda of postponing the 2020 election through the most controversial constitutional interpretation taking the Covid-19 Pandemic as a pretext. Accordingly, by offering four options; namely: dissolving the Parliament; Constitutional Amendment; Declaring a State of Emergency, and Constitutional Interpretation. Finally, finally, the government has selected constitutional interpretation as a sound mechanism to postpone the 2020 political election in Ethiopia. Following this serious decision in postponing election; serious opposition have been blowing to the ruling party of Ethiopia; since 2020 to this date. Many political figures and the leaders of the Revolution, commonly known as "the Oromo Protest" which dismantled TPLF oriented EPRDF in 2018 from power have imprisoned. Consequently, Ethiopia has encountered a serious constitutional crisis; and disastrous war in Tigray at this moment. Hence, the quest for conducting free and fair election in the near future or in June 2021, and thereby ensuring limited government is remained a paradox in the present-day federalist Ethiopia.

\section{ii) Accountability, Transparency, and Limited Office Duration of Government Officials}

The concept of accountability, transparency and limited office duration of government officials has been far from the political culture of African states in general and in Ethiopia in particular! Africa as a continent has been known by its dictatorial administration even in post-colonial eras where a single president or prime-minister claims to rule the country for lifelong. For instance, the Case of former Colonel Muammar Al Gaddafi of Libya, former Robert Gabriel Mugabe of Zimbabwe, former Omar Al-Bashir of Sudan, the Late Prime-Minister Meles Zenawi of Ethiopia; and the present-day, Isaias Afwerki of Eritrea, Ismael Omar Guelleh of Djibouti, President Yoweri Museveni of Uganda and others. All these countries' Presidents and Prime- Minister Powers have never known accountability, transparence and limitation of duration of time on power. They have been ruling their respective countries, without accountability, transparence and limitation of time concerning their term of office. In democratic leadership, both the elected and appointed government officials cannot escape from responsibility under democratic leadership. This responsibility is both legal and political. If the representatives of the people didn't fulfill their duty in favor of the people or the constituency who elected them, they will punish them with their cards up on election; so the right to elect is one guarantee to ensure accountability. Consequently the right to elect/vote is the best instrument through which the unproductive representatives are evicted from their seat. In addition to this, any government officials are subjected to legal punishment and court trial according to the law if they commit crime.

On the other hand, the concept of transparency has a tight relationship with accountability. Transparency for instance has to be measured against clear standards and requirements to be placed in detailed legislations and similarly accountability may be ensured by putting in place clear duties and responsibilities of the appointed and elected officials in various laws that pertain to their areas of operation, and by penal legislation in case of violations (Getachew, 2012).

Additionally, concerning the term offices of the presidents and Prime-ministers of the African states have hardly limited in their constitutions and absolutely unlimited as we understand from practices. Many of the African presidents and prime ministers came into powers through not peaceful manner; for instance, they came into power by military coup, and by war, and conflicts through overthrowing one another.

For instance, President Omar Al-Bashir has led Sudan since he took power in a military coup in 1989 and was nominated as NCP's presidential candidate and has been ruling Sudan until he himself was disposed from 
power through military coup last year. Since Eritrea gained independence from Ethiopia on May 24, 1993, until today; President Isaias Afwerki has been ruling Eritrea without any election or interruption. Furthermore, Ethiopia had been ruled under the late Prime-Minister Meles Zewi since 1991 up to 2011. Recently, President Museveni of Uganda has declared his winning the presidential election for six times in January 2021. Therefore, in African states in general and in Ethiopia in particular, ensuring accountability, transparency and limiting the term offices of the political leaders [presidents and prime-ministers] has never been approved until this research is done. There are prevailing human rights violations, rampant corruptions, and maladministration in Ethiopia; nevertheless, we are never witnessed when and where accountability, transparency and limitation of power are enforced on the government officials in Ethiopia.

\section{B. Lack of Adherence to Rule of Law as a Challenge to Multicultural Federalism in Ethiopia}

The phrase 'Rule of Law' is derived from the French phrase 'La Principe De Legalite' (The Principle of Legality) which refers to a government based on principles of law and not of men (Alok, 2015). However, the term 'rule of law' is a very controversial concept in legal and political studies. Hence, each and every person who defines the term rule of law has defined it as per their respective interest. Accordingly, political leaders, international organizations and academicians defined the term rule of law in various manners. However, as a consensus, the term rule of law is revolving around establishing a limited government in certain country. The nature of limitations will vary with the society, culture, political and economic arrangements; but the need for limitations on the government will never be obsolete, where and when rule of law is respected (Brian Z, 2004).

Today, the Rule of Law is the foundation of good governance. This requires adherence to constitutional supremacy, recognition that government and the governed are equal before the law, acknowledgment that government itself is limited by the law and cannot engage in any arbitrary exercise of power, and recognition that individuals are endowed with certain inalienable rights that cannot be denied even by legitimately constituted governments (Alok, 2015).

Nevertheless, the concept of rule of law is hardly practiced in Ethiopia since its establishment as a country. Of course, rule of law is depend up on the notion that claims powers of state and government can be exercised legitimately only in accordance with the applicable laws and according to laid down procedures; which is almost very rare in Ethiopia. The People of Ethiopia have been governed by the arbitrary decisions of their rulers; not according to the law and procedures laid down beforehand as one can witnessed from her political history. In Ethiopia, supremacy of constitution, sovereignty of the people, sanctity of human rights, independency and impartiality of judiciary, and separation of powers are completely elusive though all these concepts are incorporated in their constitutional texts. Furthermore, presently Ethiopia has been suffering from rampant corruption, internal conflict, civil strife, massive internal displacement, and other related problems. Consequently, it is impossible to talk about rule of law in the midst of all these chaos, which seriously violate the principles of rule of law. As a result of this, straightening the system of multicultural federalism in the midst of all these hells in the contemporary Ethiopia remains a political anomaly.

\section{C) Violation of Human Rights in the Multicultural Ethiopian Federation}

Ethiopia has remained one of the most conflicted and unstable state in Africa. The causes of these conflicts may include: failure in managing diversity, state formation and governance, as well as, forms of engagement with outside cultures and influences (Redie, 2013). Accordingly, whether seen from the perspective of state, intrastate and inter-state conflicts; the absence of peace in Ethiopia in particular and in the Horn of Africa in general has its roots in a long and complex history, political economy, state formation processes and struggles, international intervention, identity conflicts and environmental change (Ibid). As a result of this vicious circle conflicts and war both internally and externally, gross human rights violations have been ongoing in Ethiopia both by state actors and non-state actors. Consequently, these gross violations of human rights at a wide range have been becoming a viable challenge to the advancement of multicultural federalism in the contemporary Ethiopia in various aspects.

\subsubsection{Dissenting Political Ideologies as a Challenges to Multicultural Federalism in Ethiopia}

Hereinabove, I have assessed that the Horn of African states in general and Ethiopia in particular had disturbed because of various reasons like colonization, inter-state and intra-state conflicts, and lack of constitutionalism. The Horn states which Ethiopia is a center of all have been remained the center of crises and conflicts as a reasons of dissenting political ideologies even in the post-1991 [after the collapse of communism at global level]. Almost, all the country of the Horn states of Africa including Ethiopia have been disintegrating even in the postindependence era from European colonialism. For instance, Eritrea was seceded from Ethiopia in 1991. The Somali Republic, which was created in 1960, had split into Somaliland (a former British colony) and Somalia (a former Italian colony). The Southern Sudan was seceded from the Sudan in 2011. Consequently, the former three countries now duplicated and become six countries. Despite all these continuous disintegrations, still there are a number of political question which have remained unsolved in the Horn of Africa. One of the greatest of all these questions in this sub-continent in which Ethiopia is a center is the prevailing dissenting political ideologies which can mainly categorized as: federalist, secessionists, unionists and extremists ideologies. 
However, this paper put its emphasis only on assessing of the dissenting political ideologies which destabilizes the Ethiopian state, and thereby, retarding the present-day system of multicultural federalism in the same country. Therefore, these political ideologies have assessed in the following manners as a challenges to the nurturing of multicultural federalism in contemporary Ethiopia.

\section{a) Unionists and Federalist/Secessionists Ideology}

The Horn of African States in general and Ethiopia particular were created through war and conquest as one can understand from history. Therefore, the model of state formation and political organization is hierarchical (Daniel, 1987). In this form of government system everything is imposed from above including the constitution itself (Ibid). The subjects/citizens' interest in all aspects are not considered; hence the ruler made all their laws to suppress the nation for their own interest. For instance, states formed through conquest, dictatorship, and Monarchical government is categorized under this model.

Hence, in this form of governance where state/country was established through war, conquest and expansion through aggression, those who had the political powers in their hands are interested to unify the country more and more to strengthen their political powers. For instance, either they may employed the 'assimilation policy' like the French model during the colonial era; or they may utilize 'divide and rule policy' like the Great Britain, to suppress the people they have subjugated into their empire. Consequently, these groups always show up themselves as unionists in their political ideologies. Nevertheless, the subjugated people or groups are always struggling to regain their independency through war of independence under the guise of the right to self-determination. These political groups may organize themselves as a Liberation Front or Freedom Fighters conducting sporadic or continuous war against the central governments to secede from the main countries or at least to ensure the functioning of genuine multicultural/multinational federalism. As a result of this, these political forces may be nominated by different names. Hence, they call themselves as Freedom Fighters struggling to guarantee and enforce the right to self-determination for their people/ethnic group from the suppression of the central government which opt to ensure the interest of certain dominant groups, like dominant language, culture, religion and others, to ensure/strengthening the unity of the country through disregarding the prevailing diversities in the country; may be to uphold the system of unitary state. Nevertheless, the central government/ruling government and the unionist political camps, labeled such political parties/Liberation Fronts as secessionist/separatist/the force of disintegration; in the worst scenario, terrorist groups.

For instance, in Ethiopia we have political parties as unionist forces; they strongly condemned federalism; especially multicultural federalism as a dangerous political ideologies. They claimed for unitary states and striving a lot to change the current federal state structure of Ethiopia to unitary state, or readjust it in the form of geographical federalism. For instance, Ethiopia Citizens for Social Justice or ECSJ Party (formed in May 2019 from 7 other parties, including Patriotic Genbot 7, Ethiopian Democratic Party (EDP), All Ethiopian Democratic Party (AEDP), Semayawi Party, New Generation Party, Gambella Regional Movement (GRM), Unity for Democracy and Justice (UDJ) Party; Balderas, and National Movement of Amhara Parties are the core one.

On the other hand, there are a number of political parties who strongly claimed for further regional autonomy and multicultural federalism. These groups of political parties have been struggling to ensure genuine and functioning multicultural federalism in Ethiopia. However, they are determined themselves to enforce their right to self-determination up to independence/secession; rather than losing their national identity under the guise of unity or restoring unitary state by the unionist forces moving in Ethiopia. The main federalist forces /claimant of multicultural federalism in present-day Ethiopia includes: The Oromo Liberation Front [OLF]; the Ogadinian National Liberation Front [ONLF], The Tigray Liberation Front [TPLF] now at war with the central government of Ethiopia, the Sidama National Liberation Front (SNLF) and others in Ethiopia. Accordingly, these political groups considered the federal system as a minimum bench marks to stay tighter in the state of Ethiopia.

\section{b) Extremist Political Ideology [Religious/Political Extremism]}

Of course, extremism and terrorism is becoming the global problem in the current world. Similarly, Ethiopia never escapes from the impact of extremism or radicalism. The nature of radicalism in Ethiopia may be both in political and religious aspects. Political radicalism in Ethiopia has been revealed in extreme chauvinism which considered Ethiopia as a country of one religion, one flag, and language. The lovers of the previous/ancient absolute kings of Ethiopia considered these absolute kings like, King Minilik II, Haileselassie I, as sacred kings and the father of Ethiopia, through disregarding the contributions of the others in building Ethiopia. Whereas, the other suppressed Nations, Nationalities and Peoples of Ethiopia considered these previous Ethiopian kings as a colonialists and suppressors.

On the other hands, some religious followers considered Ethiopia as holy land/ Christian Highland/ and country which has unique connection and places from God. Additionally, the threat from Al-Shabaab, an Islamist based movement in the Horn of Africa, basing its center in Somalia is also not simple. The AlShabab's attacks have been targeting the Transitional Federal Government Officials and infrastructures in Somalia; however, later it has been targeting government offices, Ethiopian Consulates, the United Nations Development Compounds and any interests of the Western and Ethiopian interests (Roland, 2011). The Al- 
Shabab's first attack outside Somalia was occurred on July 11, 2010 when suicide bombers set off two coordinated blasts inside a restaurant and a rugby club in Kampala, Uganda, where international crowds had gathered to watch the World Cup (Ibid). Though Al-Shabab is an Al-Qaeda affiliated organization moving in Somalia to establish an Islamist State of Somalia; Ethiopia is also seriously affected by this extremist groups in multiple ways.

\section{Conclusions}

The establishment of Ethiopia as a modern state is too contentious in the perspectives of history, politics and laws. Since, its establishment as a modern state in the late $19^{\text {th }}$ century by Minilik II to this date, Ethiopia has been utilizing three different political ideologies and system of governance; namely, monarchical, socialist and federalist. In both under monarchical and socialist regime i.e. from1889-1991 Ethiopia had remained under unitary state structure, though there was a paradigm shift in political ideology from monarchical to socialist state system. This paradigm shifts from feudalism/monarchical to socialism upon the 1974 Revolution ensured the creation of classless society. Nevertheless, the 1974 Revolution had never answered the quest for national identity or ethnic identity. That was why the 1991 Revolution was taken place and resulted in multicultural/multinational federalism state structure and governance system in Ethiopia.

Consequently, Ethiopia has started to practices multicultural federalism as its state and government since 1991, and constitutionalized this system through adopting and enforcing the 1995 FDRE Constitution in the $21^{\text {st }}$ day of August, 1995. This constitution basis its pillars on the principles of multicultural federalism like, giving recognition to the Ethiopian Nations, Nationalities and Peoples; guaranteeing the unconditional rights to selfdetermination up to secession, and recognizes the equality of languages, culture, religion etc.

Nevertheless, several prevailing challenges have been blowing to the multicultural federalism since its inception in Ethiopia. These challenges can be categorized as historical, political, and legal challenges in general. Accordingly, dissenting political complicatedness, for instance, the tension between the federalist and unionist forces sandwiched the system of multicultural federalism in contemporary Ethiopia. Again, the extremist in any aspects; either religious or ethnic oriented extremism has great impact on the system of multicultural federalism in current Ethiopian federation.

On the other hand, the concept of limiting governmental powers; adherence to the rule of law; and the protection of human rights; or shortly the principle of constitutionalism has never ever practiced by the Ethiopian government to this date. Ethiopia has never conducted free and fair election in her political history. As adding insults to injury, the ruling party has postponed the 2020 National Election of Ethiopia in a very controversial manner last year. The term office of the Prime-Minister [head of the government] is not limited constitutionally in Ethiopia until this paper is written. Currently, Ethiopia is blamed by the World Communities and International Organizations, as well as, by the Opposition Political Parties registered and moving in the country for the ongoing Internal Conflicts/War, Gross Human Rights Violation, and Massive Internal Displacement.

To sum up, these multiple historical, political and legal challenges are creeping towards the present-day Ethiopian multicultural federalism. Therefore, the researcher would like to recommend all the concerned organs [the government, the opposition political parties, and the Ethiopian Nations, Nationalities and Peoples] that there is no way to save Ethiopia from disintegration, except sticking to multicultural/multinational federalism in the contemporary politics.

\section{Reference}

Abdiwahab Hussein Mohamed (2013), Constitutionalism in Africa: a Comparative Study of Kenya and Somalia, $2004-2012$.

Alok Kumar Yadav (2015), International Journal of Law and Legal Jurisprudence Studies (ISSN: 2348-8212: Volume 4 Issue 3) available at: http://www.lawteacher.net.

Brian Z. Tamanaha (2004), On the Rule of Law: History, Politics and Theory (Cambridge: Cambridge University Press):101

Constitution of the Federal Democratic Republic of Ethiopia, [Proclamation No. 1/1995. Federal Negarit Gazeta. 1st Year, No. 1. Addis Ababa, 1995].

Daniel Elazar (1987), Exploring Federalism (Tuscaloosa, AL: University of Alabama Press).

Ferran Requejo (2005), Multinational Federalism and Value Pluralism, the Spanish Case (Routledge Series in Regional and Federal Studies; Edited by John Loughlin):94

Getache Assefa (2012), Ethiopian Constitutional Law, with comparative notes and materials, a text book, School of Law, Addis Ababa University, published by American Bar Association, 321 North Clark Street, Chicago, Illinois, USA.

Graham Smith (1995), 'Mapping the Federal Condition: Ideology, Political Practice and Social Justice' in Graham Smith eds. Federalism: The Multi-ethnic Challenge (London: Longman): 5-6.

Jean-Francois (2011), Federation and Federalism: Encyclopedic Dictionary of Public Administration: The 
Reference for Understanding Government Action, accessible at, www.dictionnaire.enap.ca

John Kincaid (1995), 'Values and Value Tradeoffs in Federalism,' Publius: The Journal of Federalism 25:2 (Spring 1995):30-31.

John Young (1998): Regionalism and Democracy in Ethiopia (vol.19, No.2) Stable

K.C. Wheare (1963), Federal Government, $4^{\text {th }}$ ed. (London: Oxford University Press, 1963): 244-245.

Kahn Paul W (2003), Comparative Constitutionalism in A New Key" (Michigan Law Review 101, no. 8(August 2003)): 2677-2705.

Michael Burgess (1993), 'Federalism as Political Ideology: Interests, Benefits and Beneficiaries in Federalism and Federation,' in M. Burgess and A. Gagnon eds., Comparative Federalism and Federation (London: Harvester, 1993):102-113.

Preston King (1982), Federalism and Federation (London: Croom Helm, 1982).

Redie Bereketeab (2013), The Horn of Africa: Intra-State and Inter-State Conflicts and Security, (First published 2013 by Pluto Press, 345 Archway Road, London N6 5AA):13-14

Roland Marchal (2011), The Rise of a Jihadi Movement in a Country at War Harakat Al-Shabaab AlMujaheddin in Somalia, (Senior Research Fellow at CNRS, Sciences Paris):4

Stanford Encyclopaedia of Philosophy (2016): The Stanford Encyclopaedia of Philosophy is copyright (C) 2016 by The Metaphysics Research Lab, Center for the Study of Language and Information (CSLI), Stanford University, Library of Congress Catalog Data: ISSN 1095-5054.

The European Union Election Observation Mission Final Report on the Ethiopia Legislative Elections of 2005.

Thomas Fleiner and Lidija Basta (1996), 'Federalism, Federal States and Decentralization' in Lidija Basta and Thomas Fleiner eds., Federalism and Multiethnic States: The Case of Switzer land (Fribourg: PIFF, 1996):34.

Ugo Mattei (1995), The new Ethiopian constitution; First Thought on Ethnical Federalism and the Reception of Western Institutions (1995):6.

URL:http://www.jstor.org/stable/3993156):194.

William Riker (1964), Federalism: Origin, Operation, and Significance (Boston: Little, Brown and Company). 